\title{
A Toponymic Bibliography: Books, Articles, and Selected Papers by Donald J. Orth
}

\author{
Margaret S. Powell
}

The College of Wooster

Abbeville, Smackover, and Fond du Lac: French influence on the toponymy of the United States. With Jean-Claude Boswell-Thomas. International Geographical Congress (25th: 1984: Paris, France, 2731 August 1984). Typescript.

About a dollar-a-pound: story of the "Dictionary of Alaska place names." 1999. 7p. Typescript.

Alaska place names \& USGS maps. Fairbanks, AK: Scarp Exploration, Inc., 1998. One computer laser optical disc. Electronic version of Orth's Dictionary of Alaska place names, q.v.

American folklore atlas and the cartographer. American Folklore Society Meeting (1972: University of Texas, Austin, November 1619, 1972). Typescript.

Aspects of toponymic research. American Name Society Annual Meeting, New Orleans, December 27-30, 1988. Typescript.

Authorities and organizations involved with geographic names-1985:

United States, Canada, Mexico. 2nd ed., rev. Reston, VA: U.S.

Dept. of the Interior, Geological Survey, National Mapping Division, Office of Geographic and Cartographic Research, 1985. vii, 95p. (U.S. Geological Survey Open File Report 85-305). Earlier edition has title: Official authorities \& other organizations involved with geographic names, q.v.

Authorities and organizations involved with geographic names: United States, Canada, Mexico. 3rd ed., rev. Reston, VA: U.S. Geological Survey, 1989. vii, 116p.

Aux Arcs and Trucker's Terror. Names Institute (12th: 1973: New York). 12p. Typescript. 


\section{Names 48.3/4 (September/December 2000)}

Before the beginning: the U.S. Board on Geographic Names. National Geographic Society, Washington, DC: 1990. 8p. Typescript.

"Cartotoponymy research in the United States." Pan American Institute of Geography and History. General Assembly (13th: 1986: Rio de Janeiro and Brasilia, Brazil, 14-18 April 1986). [Proceedings.] México, D.F.: The Institute, 1986. 10p. Also presented at the International Congress of Onomastic Sciences (15th: 1984: Leipzig, 1317 August 1984).

A century of toponymic service. Blue Ridge Onomastic Symposium, 4th: 1989: Roanoke (VA) City Library, April 22, 1989. Typescript.

Chronological history of annual meetings of the American Name Society: officers, locations, dates, events, and policies. 1984. 73p. Typescript.

Coulet du Gard, René, and Dominique Western Coulet. Handbook of American counties, parishes and independent cities. [Newark, DE]: Editions des Deux Mondes, 1981. vi, 500p. Review by Orth in Onomastica Canadiana 61 (June 1982): 22-24.

"The creation." In The United States Board on Geographic Names, 1890-1990. Yesterday, today and tomorrow. Proceedings of a centennial symposium. [Washington, DC], September 6-7, 1990. Meridian No. 8 (1992): 17-20.

Dam and reservoir names. American Name Society Annual Meeting, Philadelphia, December 28, 1960. 8p. Typescript.

Delaware place names. By L. W. Heck, Donald J. Orth, et al. Washington, DC: U.S. Government Printing Office, 1966. iii, 124p. (U.S. Geological Survey Bulletin 1245).

Diary of actions, policies, and events: 1890-1990. United States Board on Geographic Names. 2000. 710 p. Typescript.

Dictionary of Alaska place names. Washington, DC: U.S. Government Printing Office, 1967. xi, 1084p. (U.S. Geological Survey Professional Paper 567). Reprinted with minor revisions, 1971. Electronic version, 1998, has title: Alaska place names \& USGS maps, q.v.

"Did someone say-bored of geographic names?" USGS Newsletter 2.3 (September 1980): 5-8.

"Domestic geographic names activity in federal mapping." Surveying and Mapping 24.4 (December 1964): 603-06. Presented at the American Congress on Surveying and Mapping (23rd: 1963: Washington, DC, March 26-29, 1963), and at the Names Institute (2nd: 
1963: Fairleigh Dickinson University, Madison, NJ). Received ACSM award.

"Domestic geographical names standardization in the United States." 450 ans de noms de lieux français en Amérique du Nord. 1984. Québec: Les Publications du Québec. p. 86-88. First International Congress on French Toponymy in North America, Québec, Qué., 11-15 July 1984.

Field collection procedures: Native American placenames. Reston, VA:

U.S. Board on Geographic Names. 1988. 41p. Typescript.

Field investigation of Native American placenames: U.S. Board on Geographic Names. With others. Washington, DC: U.S. Forest Service, 1989. Leaflet.

The field of cartotoponymy. American Name Society Annual Meeting, San Francisco, December 28-30, 1987. Typescript.

Field procedures for the investigation of Native American placenames.

Document submitted to the United Nations Group of Experts on Geographical Names (14th Session: 1989: Geneva, Switzerland, 2131 May 1989). Working Paper 29.

First encounters of the virgin kind. Canadian Society for the Study of Names, University of British Columbia, Vancouver, 2-4 June 1983. 14p. Typescript.

From Abbeville to Zuni: placenames on topographic maps. Washington, DC: U.S. Geological Survey, 1971. 19p. Leaflet.

"From the Snakeden to the Frying Pan; or Reston-with a lick and a folly." In U.S. Geological Survey. Water Resources Division. WRD Bulletin January-March (1974): 1-7.

. U.S. Geological Survey. Topographic Division. Eastern Mapping Center. the emcee (1974): 3.3-4.

Generic terms in placenames. 1974. 11p. Typescript.

Geographic names. Washington, DC: U.S. Geological Survey, 1967. 9p. Leaflet.

"Geographic names." In Geological Survey (U.S.). Suggestions to authors of the reports of the United States Geological Survey. 5th ed. Washington, DC: U.S. Government Printing Office, 1958. p. 92-99. 6th ed. Washington, DC: U.S. Government Printing Office, 1978. p. 159-66. 7th ed. [Reston, VA]: U.S. Dept. of the Interior, Geological Survey, 1991. p. 83-90. 


\section{Names 48.3/4 (September/December 2000)}

"Geographic names." In Geological Survey. (U.S.). Topographic Division. Topographic instructions of the United States Geological Survey. Washington, DC: U.S. Government Printing Office. Book 3: Part A. Chapter 9. 1961. 14p. Revised edition has title: "Names on a map." 1979, q.v.

Geographic names and the federal government: a bibliography. Washington, DC: Library of Congress, Geography and Map Division. 1990. ii, 59p.

"Geographic names and the public interest." Surveying and Mapping 29.4 (December 1969): 651-54.

Geographic names: servant of language, history, and geography. National Council of Teachers of English Annual Meeting, Honolulu, November 23-25, 1967. 10p. Typescript.

GNIS and the National Gazetteer. Association of American State Geologists, Little Rock, AR, June 4, 1979. Typescript.

Goals and methodology in placename research. American Name Society Annual Meeting, Chicago, 1985. Typescript.

"Guidelines for beginning a geographical name information file." Coauthored with Rolf Böhme. In United Nations Conference on the Standardization of Geographical Names (4th: 1982: Geneva, Switzerland. 24 August-14 September 1982). [Proceedings.] New York: United Nations, 1987. Vol.2. Technical papers. p. 241-2. U.N. document: E/CONF. 74/L.97.

"Guidelines for establishing a national geographical names authority and planning a standardization programme." In World Cartography. New York: United Nations, 1986. Vol.18. p. 9-16.

Guidelines for preparing and submitting proposals regarding domestic geographic names. United Nations Conference on the Standardization of Geographical Names (1st: 1967: Geneva, Switzerland, 422 September 1967). [Proceedings.] New York: United Nations, 1969. Vol.2. Proceedings of the conference and technical papers. p. 105-15. U.N. document: E/CONF. 53/L.33. Earlier version: Washington, DC: U.S. Geological Survey, U.S. Board on Geographic Names, Domestic Names Committee, 1967. 19p. Typescript.

Guidelines for the use of official geographic names. Western States Geographic Names Conference, 5th: 1981: Timberline Lodge, OR, October 22-23, 1981. Typescript. 
Indian and Eskimo place names. Names Institute, 1st: 1962: Fairleigh Dickinson University, Madison, NJ, May 5, 1962.11p. Typescript. "International boundary names: United States, Canada and Mexico." In United Nations Conference on the Standardization of Geographical Names (5th: 1987: Montréal, 18-31 August 1987). [Proceedings.] New York: United Nations, 1991. Vol.2. Technical papers. p. 44850. U.N. document: E/CONF. 79/L.17.

"Introduction: geographical names." In World Cartography. New York: United Nations, 1986. Vol.18. p. 3-8. Covers the history of the international standardization of geographical names and the organizations and procedures for standardization in several countries.

Manual for the national standardization of geographical names for the United Nations. United Nations Group of Experts on Geographical Names, 11th Session: 1984: Geneva, Switzerland, October 1984. Draft copy of "Guidelines for establishing a national geographical names authority and planning a standardization programme," q.v.

Members, officers, and major contributors: the United States Board on Geographic Names and its committees, 1890-1990. 2000. 150p. Typescript.

"Motive in placenaming." In Edward Wallace McMullen, ed. Names new and old: Papers of the Names Institute. [Lanham, MD: U P of America], 1993. p. 15-26.

Michaux State Forest, Pennsylvania, northern and central sections: (Cumberland Valley to Caledonia Park). By David R. Wones and Donald J. Orth. 6th ed. Washington, DC: Potomac Appalachian Trail Club, 1974. One map by Orth.

The mission and activities of the U.S. Board on Geographic Names: domestic names. Presented at the First International Congress on French Toponymy in North America, Québec, Qué., 11-15 July 1984. Typescript.

Mount McKinley-Denali name-change case. 1977. 125p. Typescript.

"The mountain was wronged: the story of the naming of Mount Rainier and other domestic names activities of the U.S. Board on Geographic Names." Names 32.4 (1984): 428-34. (Meredith F. Burrill festschrift issue.)

"Names on a map." In Geological Survey (U.S.). Topographic Division. Topographic instructions of the United States Geological Survey. 


\section{Names 48.3/4 (September/December 2000)}

Rev. [Menlo Park, CA: The Survey, 1980]. Book 4: Part B. Chapter 5. 1979. 35p. Earlier edition has title: "Geographic names." 1961, q.v.

"The National Gazetteer of the United States of America." In United Nations Conference on the Standardization of Geographical Names (4th: 1982: Geneva, Switzerland, 24 August-14 September 1982). [Proceedings.] New York: United Nations, 1987. Vol.2. Technical papers. p. 271-77. U.N. document: E/CONF. 74/L.101.

National Gazetteer of the United States-New Jersey 1983; Delaware 1983; Kansas 1984; Arizona 1986; Indiana 1988; South Dakota 1989; North Dakota 1990; Florida 1992. Prepared by the U.S. Geological Survey in cooperation with the U.S. Board on Geographic Names. Washington, DC: U.S. Government Printing Office. Orth wrote individual introductions to each of the volumes.

National Gazetteer of the United States-United States Concise. Prepared by the U.S. Geological Survey in cooperation with the U.S. Board on Geographic Names, 1990. Washington, DC: U.S. Government Printing Office. Orth wrote the introduction.

"A national geographic names data base." Canoma 6.1 (1980): 25-30. Presented at the International Symposium on the Computerization of Geographical Names, Ottawa, Canada, 3-4 June 1980. 17p. Also Spanish translation: Una base de datos nacional de nombres geográficos. 1981, q.v.

The National Geographic Names Data Base compilation procedures: Phase II. United Nations Conference on the Standardization of Geographical Names (5th: 1987: Montreal, 18-31 August 1987). [Proceedings.] New York: United Nations, 1991. Vol.2. Technical papers. p. 187-245. U.N. document: E/CONF. 79/L.22. Co-authored with Roger L. Payne. Earlier version: U.S. Geological Survey Open File Report 84-036, 1984. iv, 100p.; and 2nd ed. In U.S. Geological Survey Circular 1011, 1987. v, 133p.

"The nature of topographic terms." Indiana Names 3.1 (Spring 1972): 5-18.

. In Baker, Ronald L., ed. The study of place names. Terre Haute: Indiana Council of Teachers of English; Hoosier Folklore Society, 1991. p. 44-58. Publication dedicated to Wayland D. Hand.

"North Slope geographic name sources for geologic nomenclature." In Geological Seminar on the North Slope of Alaska. Proceedings of 
the Geological Seminar on the North Slope of Alaska. Los Angeles: American Association of Petroleum Geologists, Pacific Section, 1970. 1 vol. (variously paged: A1-R10).

Official authorities \& other organizations involved with geographic names-1984: United States, Canada, Mexico. Reston, VA: U.S. Geological Survey, 1984. vi, 87p. maps. (U.S. Geological Survey Open File Report 83-881). Later editions have title: Authorities and organizations involved with geographic names, q.v.

Ole devil Haboob: names of local and world winds. Canadian Society for the Study of Names, Bishop's University, Lennoxville, Québec, 4-5 June 1999. 13p. Typescript.

"Origin of the placename Toad Suck, Arkansas." Comments on Etymology 12-13 Issue 13-14 (April 1983): 4-6.

"Origins of names of U.S. states." U.S. Department of the Interior. News Release. July 12, 1976. 12p.

. American Motorist 45.11 (November 1976): 14, 21, 24.

"Organization and functions of a national geographical names standardization programme: a manual." In World Cartography. New York: United Nations, 1990. Vol.21. p. 11-40. (Also "Organización y funciónes nacional de nombres geográficos.” Spanish translation made for the School of Cartography, Panamá, Repúblic de Panamá, 1989. 107p.)

"Place names and computers: a new challenge." Indiana Names 2.1 (Spring 1971): 2-12.

Placenames and exploration. Explorers Club (Washington Group), Washington, DC, January meeting, 1971. Typescript.

"Placenames and maps." 1989. 10p. Typescript. Cameo article written for a textbook in the series Applied cartography: concept and applications. (Columbus, OH: Merrill Pub. Co.)

Potomac and Blue Ridge toponymic tour. Co-authored with Jon C. Campbell. Reston, VA: United States Board on Geographic Names, 1990. 32p.

"Potomac Valley: Washington, DC to Great Falls, MD. Field trip." In Nine geographical field trips in the Washington, DC area. [Washington, DC: Association of American Geographers, 1968]. p. 7-11.

Principles, policies, and procedures: domestic geographic names. Reston, VA: U.S. Geological Survey, 1987. v, 42p. Published with 
revisions 1988, 1989, 1992, and with Roger. L. Payne, 1997. Preliminary online edition, 1997. http://mapping.usgs.gov/www/gnis/ pppdgn.html

. In United Nations Conference on the Standardization of Geographical Names (5th: 1987: Montreal, 18-31 August 1987). [Proceedings.] New York: United Nations, 1991. Vol.2. Technical papers. p. 115-29. U.N. document: E/CONF. 79/L.20.

"Principles, policies and procedures of the Board on Geographic Names." The Portolan; The Journal of the Washington Map Society 20 (Winter 1991).

"A programme by the United States of America for the automatic management of information on geographical names." In United Nations Conference on the Standardization of Geographical Names (3rd: 1977: Athens, Greece. 17 August-7 September 1977). [Proceedings.] New York: United Nations, 1981. Vol.2. Technical papers. p. 202-11. U.N. document: E/CONF. 69/L.35.

Topographic terms and placename generics. Southeastern Conference on Linguistics, University of Florida, Gainesville, April 3-4, 1992. Typescript.

"Toponymic guidelines for map and other editors: United States of America." In United Nations Conference on the Standardization of Geographical Names (4th: 1982: Geneva, Switzerland, 24 August-14 September 1982). [Proceedings.] New York: United Nations, 1987. Vol.2. Technical papers. p. 225-29. U.N. document: E/CONF. 74/ L.102.

. [Rev., 2nd ed.] Presented at the United Nations Regional Cartographic Conference for the Americas (3rd: 1985: New York, NY, 10 February-1 March 1985). U.N. document: E/CONF. 77/1985/CRP 4.

. Rev., 3rd ed. In United Nations Conference on the Standardization of Geographical Names (5th: 1987: Montréal, 18-31 August 1987). [Proceedings.] New York: United Nations, 1991. Vol.2. Technical papers. p. 181-86. U.N. document: E/CONF. 79/L.19. . Rev., 4th ed. 1989. Document submitted to the United Nations Group of Experts on Geographical Names (14th Session: 1989: Geneva, Switzerland, 21-31 May 1989). 19p. Working Paper 28.

Toponymic stratigraphy. Names Institute (19th: 1980: Fairleigh Dickinson University, Madison, NJ, May 1980). Typescript. 
Toponymic study of names in the United States. Names Institute (25th: 1986: Fairleigh Dickinson University, Madison, NJ, May 1986). Typescript.

"The U.S. Board on Geographic Names: an overview." Names 38.3 (1990): 165-72. Orth served as guest editor for this issue honoring the Board on its 100th anniversary.

The U.S. Board on Geographic Names: formative period. Names Institute, 30th, 1991: Baruch College, CUNY, New York, NY, May 4, 1991. Typescript.

"Una base de datos nacional de nombres geográficos." Revista cartográfica. Buenos Aires, Instituto Panamericano de Geografía e Historia, Comisión de Cartografía. Numero 39/40 (1981): 15-19. Also In Semana de Intercambio Tecnológico (Technology Exchange Week) (2a: 1982: Panamá, Repúblic de Panamá, 25-29 enero de 1982). Memoria de la segunda Semana de Intercambio Tecnológico: Panamá: SAF, [1982?] 875p. Also "A national geographic names data base," q.v.

Whatever happened to Frying Pan, Virginia? Genealogists Fair No. 2: National Archives, Washington, DC, May 11, 1974. Also presented at Names Institute, 13th: 1974: Fairleigh Dickinson University, Madison, NJ, 1974. Typescript.

"What's in a name?" In U.S. Department of the Interior. Office of Communications. In touch with people. 1973. Washington, DC: U.S. Government Printing Office, 1973. (Conservation Yearbook Series No. 9). p. 27.

"Word, thought, and landscape." Mapping and Surveying 32.3 (September 1972): 363-67. Also In U.S. Geological Survey. Water Resources Division. WRD Bulletin January-June (1972): 21-23. 